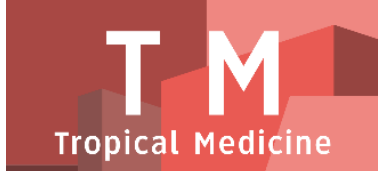

PAPER - OPEN ACCESS

Efek Kombinasi Ramuan Jamu Terhadap Tekanan Darah dan Kolesterol Pasien di Rumah Riset Jamu Hortus Medicus

\author{
Author : Peristiwan Ridha Widhi Astana \\ DOI $\quad: 10.32734 /$ tm.v1i3.281 \\ Electronic ISSN : 2623-0542 \\ Print ISSN : 2623-0550
}

Volume 1 Issue 3 - 2018 TALENTA Conference Series: Tropical Medicine (TM)

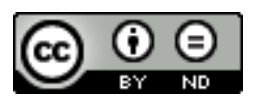

This work is licensed under a Creative Commons Attribution-NoDerivatives 4.0 International License.

Published under licence by TALENTA Publisher, Universitas Sumatera Utara
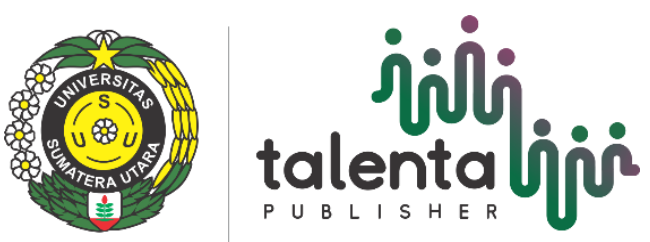


\title{
Efek Kombinasi Ramuan Jamu Terhadap Tekanan Darah dan Kolesterol Pasien di Rumah Riset Jamu Hortus Medicus
}

\author{
Peristiwan Ridha Widhi Astana ${ }^{\mathrm{a} *}$, Fajar Novianto $^{\mathrm{b}}$, Agus Triyono $^{\mathrm{c}}$ \\ ${ }^{a b c}$ Balai Besar Penelitian dan Pengembangan Tanaman Obat dan Obat Tradisional Badan Litbangkes Kementerian Kesehatan RI
}

Jl. Raya Lawu No. 11 Tawangmangu Karanganyar Jawa Tengah

drwidhiastana@gmail.com

\begin{abstract}
Abstrak
Hipertensi dan hiperkolesterolemia masih merupakan masalah di bidang kesehatan. Penanganan pasien hipertensi yang disertai hiperkolesterolemia memerlukan perhatian khusus. Di Rumah Riset Jamu (RRJ) terdapat banyak pasien hipertensi dengan hiperkolesterolemia yang diterapi menggunakan kombinasi ramuan jamu antihipertensi dan antihiperkolesterolemia. Penelitian ini bertujuan untuk mengetahui efek kombinasi ramuan jamu tersebut dalam menurunkan tekanan darah dan kadar kolesterol. Penelitian ini dilakukan menggunakan metode kohort retrospektif. Sampel didapatkan dari data rekam medik pasien hipertensi yang disertai hiperkolesterolemia di RRJ Hortus Medicus tahun 2017. Subjek penelitian ini adalah pasien yang berusia 20-65 tahun dan telah menjalani terapi kombinasi ramuan jamu antihipertensi dan antihiperkolesterol minimal 28 hari. Analisis dilakukan dengan membandingkan tekanan darah dan kadar kolesterol pasien pada hari ke-0 dan hari ke-28 masing-masing menggunakan uji t berpasangan. Sebanyak 223 data pasien didapatkan. Setelah 28 hari, terdapat 74 orang yang berhasil mencapai tekanan darah normal dan 115 orang berhasil mencapai kadar kolesterol normal. Tekanan darah sistolik berbeda secara signifikan antara sebelum dan setelah pemberian ramuan jamu, $\mathrm{p}=0,000$. Demikian juga tekanan darah diastolik berbeda secara signifikan antara sebelum dan setelah pemberian ramuan jamu $\mathrm{p}=0,005$. Kadar kolesterol di dalam darah pasien juga berbeda secara signifikan antara sebelum dan setelah pemberian ramuan jamu, $\mathrm{p}=0,014$. Berdasarkan hasil di atas, dapat disimpulkan bahwa pemberian kombinasi ramuan jamu antihipertensi dan antihiperkolesterolemia selama 28 hari dapat menurunkan tekanan darah dan kadar kolesterol pasien secara signifikan.
\end{abstract}

Kata kunci: Hiperkolesterolemia, Hipertensi, Ramuan jamu

\begin{abstract}
Hypertension and hypercholesterolemia are still being massive problem in health area. The management of patients with hypertension and hypercholesterolemia need specific concern. At Rumah Riset jamu Hortus Medicus, there are many patients with hypertension and hypercholesterolemia who get combination of antihypertension and antihypercholesterol jamu formula as theraphy. This study was conducted to know the effect of that combination to decrease blood pressure and cholesterol level. This study was conducted using retrospective cohort method. The sample were collected from medical record RRJ Hortus Medicus January - December 2017. The data were selected from patients with hypertension and hypercholesterolemia, 20 - 65 year old who received combination of hypertension and hypercholesterolemia jamu formula at least 28 days. Analysis was performed by comparing blood pressure and cholesterol between day- 0 and day-28.There are 223 patients data were collected. After 28 days, there are 74 patients with normal blood pressure and 115 patients with normal cholesterol level. The Statistical results using paired sample T-test, showed $\mathrm{p}$ value 0,000 on systolic blood pressure, $\mathrm{p}=0,005$ on diastolic blood pressure, and $\mathrm{p}=0,014$ on cholesterol. The combination can decrease blood pressure and cholesterol significantly ( $\mathrm{p}<0.05$ ). Based on the above results, it can be concluded that the combination of anthypertension and antihypercholesterol jamu formula for 28 days can decrease blood pressure and cholesterol level of RRJ patients significantly.
\end{abstract}

Keywords: Jamu formula, hypertension, hypercholesterolemia. 


\section{Pendahuluan}

Hipertensi merupakan penyakit tidak menular yang masih menjadi salah satu masalah utama di bidang kesehatan. Penyakit ini berasosiasi dengan penyakit tidak menular lainnya seperti penyakit jantung koroner, stroke dan penyakit ginjal yang disebabkan oleh hipertensi yang tidak dikendalikan secara baik [1]. Data Riskesdas tahun 2013 melaporkan prevalensi hipertensi di Indonesia pada penduduk umur 18tahun ke atas sebesar 25,8\%. Dari 15 jutapenderita hipertensi, 50\% hipertensinya belumterkendali [2].

Peningkatan kadar kolesterol merupakan salah satu dari gejala dislipidemia. Hubungan antara dislipidemia dan hipertensi telah lama diketahui dan telah banyak dilaporkan oleh banyak peneliti, namun mekanisme terjadinya hipertensi akibat dislipidemia hingga saat ini belum jelas [3].Teori yang paling kuat adalah teori aterosklerosis. Dimana Hiperkolesterolemia menjadifaktor resiko terjadinya hipertensi yang diawali dengan proses aterosklerosis pada pembuluh darah akibatterbentuknya gel busa. Akhirnya faktor pertumbuhanakan menyebabkan gel menjadi aterosklerosis lanjut yang menyebabkan hipertensi [4].

Penanganan pasien hipertensi yang disertai hiperkolesterolemia memerlukan perhatian lebih. Kecenderungan terjadi penyakit kardiovaskuler pasien tersebut menjadi lebih besar dibandingkan pasien hipertensi atau hiperkolesterolemia saja [5].

Berada di lereng gunung lawu, $40 \mathrm{~km}$ di timur kota Solo, Rumah Riset Jamu (RRJ) merupakan salah satu tempat implementasi program saintifikasi jamu. Di RRJ, berdasarkan penelitian sebelumnya pada 492 sampel yang mengalami hipertensi terdapat kadar kolesterol abnormal sebanyak 52,4\% dengan kadar rata-rata 247,2mg/dl [6]. Ramuan antihipertensi telah terbukti efektif dalam menurunkan tekanan darah dalam uji klinis tahun 2012 [7]. Ramuan antihiperkolesterolemia juga terbukti dapat menurunkan kadar kolesterol dalam uji klinis tahun 2015 [8].

Kombinasi kedua ramuan tersebut digunakan di RRJ untuk pasien hipertensi yang disertai hiperkolesterolemia.Sebagai evaluasi pemakaian kombinasi tersebut, peneliti merasa perlu untuk menilai efeknya terhadap tekanan darah dan kolesterol pasien di RRJ.

\section{Bahan dan Metode}

Penelitian ini merupakan studi kohort dengan mengambil sampel catatan medis pasien hipertensi disertai hiperkolesterolemia pada tahun 2017. Data pasien yang dinilai adalah pasien laki-laki atau perempuan berusia 20-65 tahunyang telah menjalani terapi kombinasi ramuan jamu antihipertensi dan antihiperkolesterol minimal 28 hari.Serta pasien tersebut pada kunjungan pertama mempunyaidiagnosishipertensi stage I-II sertakadar kolesterol > $200 \mathrm{mg} / \mathrm{dL}$.

Pengukuran tekanan darah di RRJ dilakukan dengan menggunakan alat tensimeter digital atau air raksa oleh tenaga medis.Pengukuran kadar kolesterol menggunakan metode spektrofotometri.Alat-alat yang digunakan di RRJ secara rutin dilakukan kalibrasi oleh Balai Pengamanan Fasilitas Kesehatan Surakarta.

\subsection{Analisis data}

Analisis dilakukan dengan membandingkan tekanan darah dan kolesterol pasien pada kunjungan pertama (Hari ke0) dengan tekanan darah dan kolesterol setelah 28 hari minum ramuan jamu (Hari ke-28).Data yang diperoleh kemudian diolah secara statistik. Jika data terdistribusi normal, maka dianalisis dengan menggunakan Uji T sampel berpasangan.

\section{Hasil Dan Pembahasan}

Dari bulan Januari sampai Desember 2017, terdapat 223 pasien hipertensi I-II yang disertai hiperkolesterol >200 $\mathrm{mg} / \mathrm{dL}$.Lebih dari dua pertiga pasien berumur lebih dari 50 tahun. Berdasarkan jenis kelamin, pasien wanita lebih banyak sekitar 2 kali lipat jumlah pasien pria. Berdasarkan usia dan jenis kelamin, Hal ini dapat dijadikan dasar bahwa 37,5\% pasien tidak bekerja karena mayoritas pasien adalah wanita dan berumur lebih dari 50 tahun. Index massa tubuh pasien $50 \%$ berada di normoweight. 
Tabel.1. Karakteristik Pasien

\begin{tabular}{|c|c|c|c|}
\hline \multicolumn{2}{|c|}{ Karakteristik } & \multicolumn{2}{|l|}{ Jumlah } \\
\hline \multicolumn{4}{|c|}{ Umur } \\
\hline- & $20-30$ th & - & $2(0,8 \%)$ \\
\hline - & $31-40$ th & - & $9(4,1 \%)$ \\
\hline- & $41-50$ th & - & $56(25,1 \%)$ \\
\hline- & $>50$ th & - & $156(69,9 \%)$ \\
\hline \multicolumn{4}{|c|}{ Jenis Kelamin } \\
\hline- & Laki-laki & - & $76(34,1 \%)$ \\
\hline- & Perempuan & - & $147(65,9 \%)$ \\
\hline \multicolumn{4}{|c|}{ Pekerjaan } \\
\hline- & Tidak bekerja & - & $83(37,2 \%)$ \\
\hline- & Tentara/Polisi/PNS & - & $11(4,9 \%)$ \\
\hline- & Pegawai Swasta & - & $17(7,6 \%)$ \\
\hline - & Wiraswasta & - & $38(17,1 \%)$ \\
\hline - & Buruh/petani & - & $34(15,2 \%)$ \\
\hline- & Lainnya & - & $40(17,9 \%)$ \\
\hline \multicolumn{4}{|c|}{ IMT } \\
\hline- & underweight & - & $11(4,9 \%)$ \\
\hline- & normoweight & - & $113(50,7 \%)$ \\
\hline - & overweight & - & $67(30,1 \%)$ \\
\hline - & obese & - & $32(14,3 \%)$ \\
\hline
\end{tabular}

Setelah 28 hari dari 223 pasien hipertensi dengan hiperkolesterolemia, terdapat 74 pasien yang memperoleh hasil tekanan darahnya normal. Sedangkan untuk kolesterol, terdapat 108 pasien yang memiliki kadar kolesterol masih di atas $200 \mathrm{mg} / \mathrm{dL}$ pada $\mathrm{H} 28$.

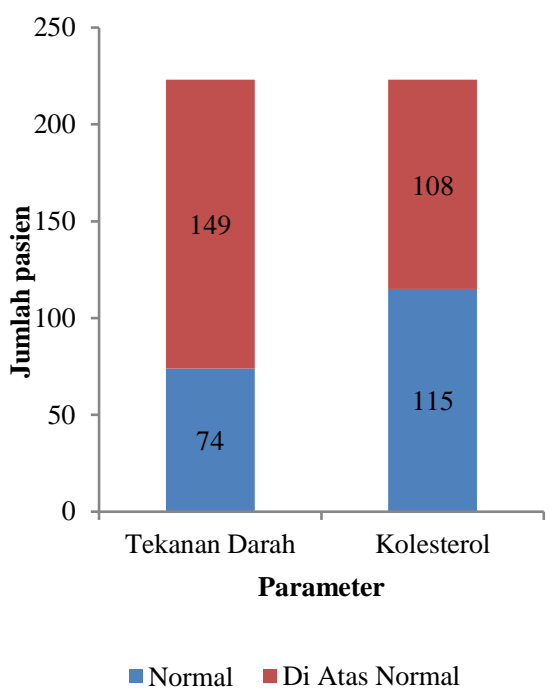

Gambar 1. Jumlah pasien yang memiliki tekanan darah normal/di atas normal di hari ke 28 
Berdasarkan catatan medis, hasil pengukuran tekanan darah pada kunjungan pertama(H0) diperoleh rata-rata tekanan darah sistolik (TDS) 164,28 $\pm 13,34 \mathrm{mmHg}$ dan tekanan darah diastolic (TDD) 96,31 \pm 6,81 $\mathrm{mmHg}$. Setelah 28 hari (H28) mendapatkan kombinasi ramuan jamu antihipertensi dan antihiperkolesterol. Rata-rata TDS menjadi $143,56 \pm 10,42 \mathrm{mmHg}$ dan TDD87,28 $\pm 5,6 \mathrm{mmHg}$.

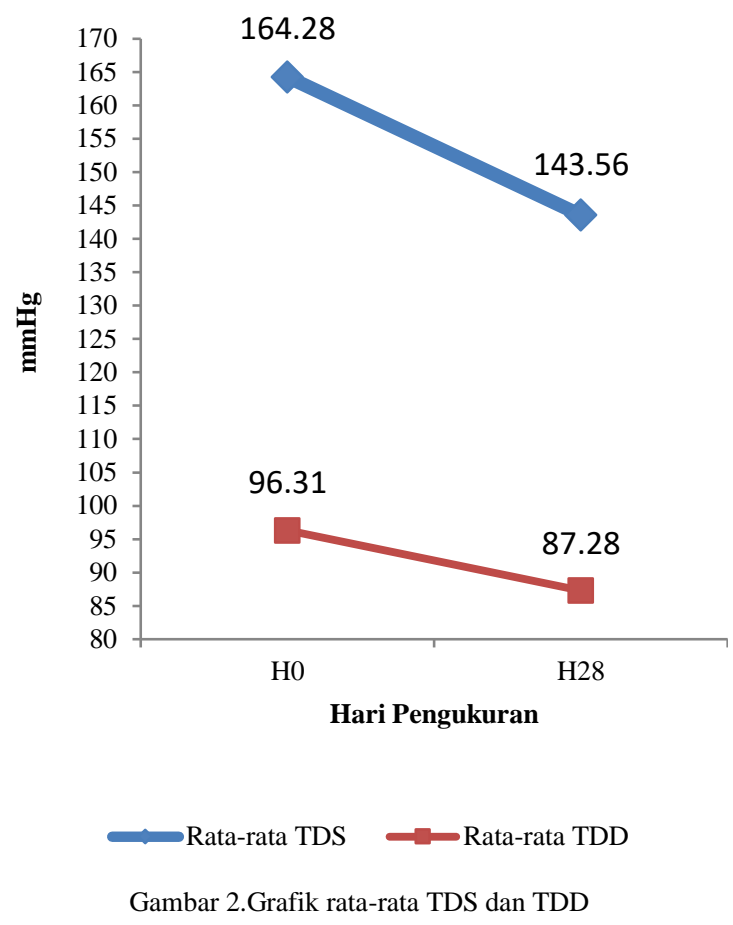

Dilihat dari grafik di atas, terdapat penurunan rata-rata TDS dan TDD pada H28 dibandingkan H0.Penurunan ratarata TDS sebesar 20,72 $\mathrm{mmHg}$ dan TDD sebesar 9,03 $\mathrm{mmHg}$.

Tabel 2. Analisis Uji T Berpasangan

\begin{tabular}{ll}
\hline Perbandingan $\mathrm{H} 0$ dan $\mathrm{H} 28$ & $\mathrm{p}$ \\
\hline TDS & 0,000 \\
TDD & 0,005 \\
\hline
\end{tabular}

Hasil analisis menggunakan uji T berpasangan didapatkan nilai $\mathrm{p}=0,000$ pada TDS dan 0,005 pada TDD. Sehingga penurunan TDS dan TDD dapat dikatakan bermakna $(\mathrm{p}<0,05)$. Penurunan tekanan darah ini, secara klinis sangat bermanfaat untuk mengurangi resikokomplikasi hipertensi. Peningkatan tekanandarah diastolik 7,5 $\mathrm{mmHg}$ yang menahun,risiko stroke dua kali lebih besar, atau akan meningkatkan risiko stroke sebesar $46 \%$. Besarnya risiko berbanding lurus dengan tingginya tekanan sistolik [9].

Akan tetapi, berdasarkan JNC VII, hasil rata-rata TDS dan TDD H28 tersebut masih masuk kategori hipertensi I.belum mencapai tekanan darah yang normal [10]. Berdasarkan penelitian, hanya 35\% pasien hipertensi dengan dyslipidemia dapat mencapai target terapi(tekanan darah normal).Hal ini sedikit lebih rendah dari respon terapi pasien dengan hipertensi saja. Hal inilah yang menyebabkan kecenderungan meningkatnya resiko komplikasi kardiovaskuler [11].

Mekanisme ramuan jamu antihipertensi dalam mengontrol tekanan darah antara lain,memberikan efek diuretic serta efek dilatasi pada pembuluh darah dan menghambat angiotensin converting enzym (ACE). Penghambatan sistem 
renin-angiotensin dapat menurunkan kemampuan ginjal dalam meningkatkan tekanan darah [7].

Rata-rata hasil pengukuran kadar kolesterol pasien pada $\mathrm{H0}$ adalah 248,34 $21,66 \mathrm{mg} / \mathrm{dL}$. Sedangkan pada hari ke 28 , rata-rata kadar kolesterol pasien adalah $219,54 \pm 22,9 \mathrm{mg} / \mathrm{dL}$.

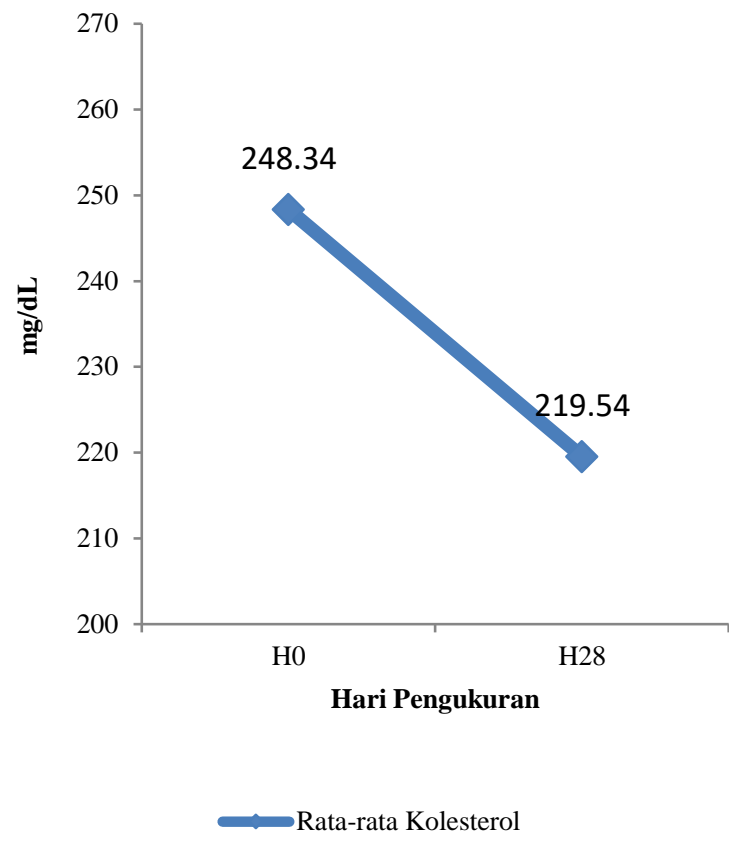

Gambar 3. Grafik rata-rata Kolesterol

Hasil analisis menggunakan uji $\mathrm{T}$ berpasangan didapatkan nilai $\mathrm{p}=0,014$. Sehingga penurunan kadar kolesterol pada pasien tersebut dapat dikatakan bermakna $(\mathrm{p}<0,05)$.

Mekanisme yang memungkinkan penurunan kadar kolesterol pasien yang diberikan ramuan jamu antihiperkolesterol adalah sifat memperbaiki profil lipid darah dengan menghambat aktivitas enzim lipase pankreas, sehingga hidrolisis trigliserida menjadi monogliserida dan asam lemak yang bisa diabsorpsi usus akan terhambat pula [12] [13].

Terdapat lebih dari 50\% pasien tidak mencapai kolesterol $<200 \mathrm{mg} / \mathrm{dL}$. Hal ini dipengaruhi berbagai factor. Beberapa faktor yang dapat meningkatkan kadar kolesterol total dalam darah adalah faktor usia dimana semakin bertambahnya usia maka elastisitas pembuluh darah semakin berkurang. Pada wanita yang memasuki masa menopause, mereka akan mengalami penurunan produksi hormon estrogen [14].

Selain itu, pola asupan makanan yang tidak sehat yaitu mengkonsumsi makanan berlemak secara berlebihan serta pola hidup yang tidak baik seperti kurangnya aktivitas olahraga juga dapat menjadi penyebab kenaikan kolesterol total [15]. Perubahan gaya hidup seperti pola makan yang menjurus ke sajian siap santap yang mengandung banyak lemak, protein dan garam tinggi serta rendah serat, obesitas/kegemukan, merokok, mudah stres merupakan salah satu faktor berkembangnya penyakit degeneratif seperti hipertensi yang dapat mengakibatkan kolesterol LDL meningkat [16].

\section{Kesimpulan}

Berdasarkan hasil di atas, dapat disimpulkan bahwa kombinasi ramuan jamu antihipertensi dan antihiperkolesterolemia selama 28 hari dapat menurunkan tekanan darah dan kadar kolesterol pasien RRJ secara 
signifikan. Setelah 28 hari, terdapat 74 orang yang berhasil mencapai tekanan darah normal dan 115 orang berhasil mencapai kadar kolesterol normal.

\section{Ucapan Terima Kasih}

Penulis mengucapkan terima kasih kepada Kepala B2P2TOOT, Panitia Pembina Ilmiah dan seluruh pegawai RRJ Hortus Medicus yang telah membantu penulis dalam menyelesaikan penelitian ini.

\section{Daftar Pustaka}

[1] Yogiantoro M. (2007). Hipertensi esensial. Dalam: Sudoyo A, Setyohadi B, Alwi I, Simadibrata M, Setiati S, editor. Buku Ajar Ilmu Penyakit Dalam Jilid I. Jakarta: Pusat Penerbitan Departemen Ilmu Penyakit Dalam Fakultas Kedokteran Universitas Indonesia. hlm.610-14

[2] Riskesdas.(2013). Kementerian Kesehatan RI. Jakarta.

[3] Darmastomo, P. dan Wirawanni, Y. (2009). Hubungan Antara Persentase Lemak Tubuh, Lingkar Pinggang, Kolesterol Total Darah, Dan Trigliserida Darah Dengan Tekanan Darah (Studi Pada Pegawai Negeri Sipil SMA 8 Semarang) (Doctoral dissertation, Program Studi Ilmu Gizi UNDIP). Semarang.

[4] Arthur CG, John EH.(2008). Metabolisme lipid.Dalam: Luqman YA, Huriawati H, Andita N,Nanda W. Ed. Indonesia. Buku Ajar Fisiologi Kedokteran. Edisi ke-11. Jakarta: EGC.hlm.882-94

[5] Johnson, M.L., Pietz, K., Battleman, D.S. and Beyth, R.J., (2004). Prevalence of comorbid hypertension and dyslipidemia and associated cardiovascular disease. heart disease (CHD), 2, p.3.

[6] Astana, P.R.W. dan Triyono, A., (2017). Gambaran Profil Lipid Pada Pasien Hipertensi Di Klinik Saintifikasi Jamu Hortus Medicus Tawangmangu. Jurnal Farmasi Galenika, 4(Edisi Khusus), pp.63-67.

[7] Triyono, A., Zulkarnain, Z. and Mana, T.A., (2018). Studi Klinis Ramuan Jamu Antihipertensi pada Pasien Hipertensi Derajat I. Jurnal Kefarmasian Indonesia, 8(1), pp.17-25.

[8] Triyono, Agus. 2015. Uji Klinis Ramuan Jamu Antihiperkolesterolemia Dibanding Simvastatin. Laporan Penelitian. Balai Besar Litbang Tanaman Obat dan Obat Tradisional.Tawangmangu.

[9] Rahajeng, E. and Tuminah, S., (2009). Prevalensi hipertensi dan determinannya di Indonesia. Majalah Kedokteran Indonesia, 59(12), pp.580587.

[10] Giles, T.D., Berk, B.C., Black, H.R., Cohn, J.N., Kostis, J.B., Izzo, J.L. and Weber, M.A., (2005). Expanding the definition and classification of hypertension. The Journal of Clinical Hypertension, 7(9), pp.505-512.

[11] Johnson, M.L., Pietz, K., Battleman, D.S. and Beyth, R.J., (2006). Therapeutic goal attainment in patients with hypertension and dyslipidemia. Medical care, 44(1), pp.39-46.

[12] Gitawati, R., Widowati, L. and Suharyanto, F., (2015). Penggunaan Jamu Pada Pasien Hiperlipidemia Berdasarkan Data Rekam Medik, Di Beberapa Fasilitas Pelayanan Kesehatan Di Indonesia. Jurnal kefarmasian Indonesia, 5(1), pp.41-48.

[13] Triyono, A. and Astana, P.R.W., 2017. Uji Klinik Efek Formula Jamu Penurun Kolesterol Darah Terhadap Fungsi Hati. Jurnal Farmasi Galenika, 4(Edisi Khusus), pp.13-19.

[14] Kamso, S., dan Purwantyastuti, R. J. (2002).Dislipidemia pada lanjut usia di kota Padang. Makara Kesehatan, 6(2), 55-8.

[15] Legi, N. N. (2014).Faktor-Faktor yang Mempengaruhi Terjadinya Hipertensi di Poliklinik Interna RSUP Prof. dr. RD Kandou Manado. GIZIDO-Jurnal Ilmiah Gizi, 6(2).

[16] Supriyono, M. (2008).Faktor-Faktor Risiko Yang Berpengaruh Terhadap Kejadian Penyakit Jantung Koroner Pada Kelompok Usia< 45 Tahun (Studi Kasus di RSUP Dr. Kariadi dan RS Telogorejo Semarang) (Doctoral dissertation, Program Pascasarjana Universitas Diponegoro). 